\title{
Reflexões sobre o desenvolvimento territorial sustentável, gestão social e cidadania deliberativa: 0 caso da bacia do rio Almada (BA)
}

\author{
Edson Sadao lizuka \\ Pontifícia Universidade Católica de São Paulo \\ Fundação Escola de Comércio Álvaro Penteado \\ Sylmara Lopes Francelino Goncalves-Dias \\ Universidade de São Paulo \\ Pedro Aguerre \\ Pontifícia Universidade Católica de São Paulo
}

\begin{abstract}
Este artigo tem por objetivo discutir o desenvolvimento territorial sustentável a partir da atuação de diferentes atores sob a ótica da gestão social e o processo de cidadania deliberativa. Analisa-se a construção do "Programa de Manejo Agroambiental da Bacia do Rio Almada" na região pertencente ao território de cidadania Litoral Sul da Bahia. Organizaram-se os dados, as informações e as entrevistas por meio de estudo de caso. Para construção do caso, foi utilizada a triangulação de técnicas da história oral e do sensemaking. O caso em tela contribui para a reflexão sobre os desafios e oportunidades referentes à gestão social, indicando que o processo de cidadania deliberativa pode se constituir em estratégia necessária para o desenvolvimento territorial sustentável. Assim, fica claro que o diálogo, a participação dos atores na elaboração e implantação de políticas públicas é algo complexo, porém imprescindível, quando se almejam transformações das realidades sociais.
\end{abstract}

Palavras-chave: gestão social; cidadania deliberativa; desenvolvimento territorial sustentável; territórios da cidadania.

\footnotetext{
Artigo recebido em 17 nov. 2011 e aceito em 1o out. 2012. Os autores agradecem o apoio da Coordenadoria de Aperfeiçoamento de Pessoal de Nível Superior (Capes) por meio do Edital no 09; CII-2008 Programa Pró-Administração, onde participam como integrantes do projeto "Gestão Social: ensino, pesquisa e prática". Os autores também agradecem à Fundação de Amparo à Pesquisa do Estado de São Paulo (Fapesp) pelo auxílio financeiro para participação em reuniões científicas, concedido em 2011 para apresentação da primeira versão deste estudo.
} 
Reflexiones sobre desarrollo territorial sostenible, gestión social y ciudadania deliberativa: el caso de la cuenca del río Almada (BA)

Este artículo tiene como objetivo discutir el desarrollo territorial sostenible a partir de la actuación de los diferentes actores, desde la perspectiva de la gestión social y la ciudadanía deliberativa. Analiza la construcción del "Programa de Manejo Agroambiental da Bacia do Rio Almada" em la región que pertenece al território de ciudadania Litoral Sul de Bahia. Se organizan los datos, informaciónes y entrevistas a través de um estudio de caso. Para construir el caso, se utilizaron técnicas de triangulación de la historia oral y de sensemaking. El caso analisado contribuye para la reflexión sobre los desafios y oportunidades referentes a la gestión social, que el proceso de ciudadanía deliberativa puede constituir uma estratégia necesaria para el desarrollo territorial sostenible. Queda claro que el diálogo, la participación de los actores em la elaboración e implantación de políticas públicas es algo complejo, pero imprescindible, cuando se tiene por objeto las transformaciones de la realidad social.

Palabras clave: gestión social; ciudadanía deliberativa; desarrollo territorial sostenible; territorios de ciudadanía.

Reflections on sustainable spatial development, management and social deliberative citizenship: the case of bacia do rio Almada (BA)

This article aims to discuss sustainable territorial development from the performance of different actors from the perspective of corporate management and the process of deliberative citizenship. Analyzes the construction of the "Programa de Manejo Agroambiental da Bacia do Rio Almada" in the region belonging to the citizenship's territory of South Bahia Coast. Organized the data, information and interviews through case study. To build the case, we used triangulation techniques of oral history and sensemaking. The case in question contributes to the discussion of the challenges and opportunities related to social management, indicating that the process of deliberative citizenship may be a necessary strategy for sustainable territorial development. Thus, it is clear that dialogue, stakeholder participation in the development and implementation of public policies is a complex, but essential, when it aims transformations of social realities.

Keywords: social management; deliberative citizenship; sustainable territorial development; citizenship territories.

\section{Introdução}

Este artigo tem por objetivo discutir o desenvolvimento territorial sustentável a partir da atuação de diferentes atores sob a ótica da gestão social e o processo de cidadania deliberativa. Essa concepção nos traz elementos fundamentais para pensar a constituição do território, agregando valor ao debate sobre gestão social, cidadania, territorialidade e sustentabilidade, uma vez que complexifica a visão tradicional que considera somente a dimensão espacial do território.

Desde o início dos anos 1990 a expressão gestão social passou a fazer parte da linguagem acadêmica e de tentativas de práticas gerenciais na América Latina (Tenório, 2012). Nas duas décadas que se seguiram, foi possível verificar um esforço de pesquisado- 
res em demonstrar as diferenças entre o que pode ser considerada uma gestão tradicional ou estratégica racional e a gestão social participativa, muitas vezes, não linear (Dowbor, 1999; Fischer, 2002; França Filho, 2008, 2003; Tenório, 2005, 2012), aceitando que o conceito de gestão social é antinômico ao de gestão estratégica. Allebrandt e colaboradores (2012), Carrion (2012), Villela e Costa (2012), entre outros, tratam da análise de gestão social e desenvolvimento territorial. Outros autores buscaram analisar a convergência dos conceitos gestão social e cidadania deliberativa (Iizuka et al., 2011; Tenório et al., 2008). Estudos recentes sobre territórios agregam valor a essas considerações, atribuindo uma dupla dimensão ao conceito de território: território dado e território construído, enfatizando a dimensão social do território, que passa a ser entendido como uma construção coletiva e institucional (Abramovay, 2010; Vieira e Cazella, 2006; Cazella, 2006). O estudo de Zani (2012) aborda concomitantemente as temáticas da gestão social e do desenvolvimento territorial sustentável (DTS).

Assim, neste artigo pretende-se avançar nas reflexões acerca do DTS e sua articulação com a gestão social e a cidadania deliberativa, apontando pistas para a compreensão destes três conceitos teóricos articulados entre si. Nesse sentido, a questão de pesquisa que norteou a construção deste artigo foi: como ocorre a participação dos diferentes atores locais sob a lente da gestão social, da cidadania deliberativa e do desenvolvimento territorial sustentável?

Conforme observou Abramovay (2010:36), a abordagem do DTS no campo das políticas públicas evidencia uma nova dinâmica de ação, pois "a noção de território abre caminho para avanço notável no estudo do próprio desenvolvimento, já que convida a que se coloque ênfase na maneira como os diferentes atores — privados, públicos e associativos — relacionam-se no plano local".

Diante disso, pretende-se analisar o processo de construção e implantação do "Programa de Manejo Agroambiental da Bacia do Rio Almada". O caso ocorreu na região cacaueira pertencente ao Território de Cidadania do Litoral Sul da Bahia. Trata-se de um universo de pesquisa adequado, pois propicia o reconhecimento das potencialidades e fragilidades da comunidade local, caracterizada pelo baixo dinamismo econômico e situações de extrema pobreza de parte significativa da população. Vale observar que, embora esta experiência tenha acontecido antes da sistematização e da disseminação das chamadas políticas públicas territorializadas no Brasil, ${ }^{1}$ o fato de ela ter ocorrido a partir de uma lógica agroambiental ${ }^{2}$

\footnotetext{
${ }^{1}$ No Brasil, as iniciativas de desenvolvimento territorial tiveram início em 2003, com a criação da Secretaria de Desenvolvimento Territorial (SDT) como componente institucional do Ministério do Desenvolvimento Agrário (MDA) e a incorporação ao Programa Plurianual do Governo 2004-07, do Programa de Desenvolvimento Sustentável dos Territórios Rurais (Pronat), adotando o enfoque territorial e seus respectivos métodos e instrumentos de gestão (Sepúlveda e Guimarães, 2008).

${ }^{2}$ Agroecologia é tida como um campo do conhecimento de natureza multidisciplinar, cujos ensinamentos pretendem contribuir na construção de estilos de agricultura de base ecológica e na elaboração de estratégias de desenvolvimento rural, tendo como referência os ideais da sustentabilidade numa perspectiva multidimensional (Altieri, Gliessman, Sevilla Guzmán citados por Ferraz, 2012).
} 
possibilitou que os pesquisadores refletissem sobre questões relacionadas ao território e ao desenvolvimento territorial sustentável (DTS).

Para cumprir a proposta deste artigo, optou-se por uma abordagem exploratória de pesquisa descritivo-qualitativa. Organizaram-se os dados, as informações e as entrevistas por meio de estudo de caso (Yin, 2005; Eisenhardt, 1989). Para construção do caso, foi utilizada a triangulação de técnicas da história oral (Verena, 2004; Berg, 2004; Cassab, 2003) e do sensemaking (Weick, 1995). Procedeu-se à análise da construção e implementação do "Programa de Manejo Agroambiental da Bacia do Rio Almada" na região do Litoral Sul da Bahia em três momentos: entre 1996 e 1998, momento inicial desta iniciativa; em 2008, uma análise sob a ótica da gestão social e da cidadania deliberativa a partir da atuação dos diferentes atores. E, finalmente, em 2012, em que se desenvolveu um esforço adicional de reflexão sobre o desenvolvimento territorial sustentável. De acordo com Weick (1995), os fatos, as percepções, os acontecimentos influenciam na maneira como as pessoas vão "fazendo sentido" (sensemaking) sobre aquilo que buscam compreender. Essa forma de investigação permitiu uma análise longitudinal sobre a participação dos diferentes atores sob a ótica da gestão social, assim como da cidadania deliberativa, contextualizadas num determinado território.

\section{Gestão social, cidadania deliberativa e desenvolvimento territorial sustentável: possibilidades de convergência}

Atualmente, pensar em gestão social significa preocupar-se com as novas formas participativas, tal como descreveu Tenório (2010:2): “(...) uma gestão ampliada na qual o processo decisório seria vinculante ao diálogo consciente, procedimental, por meios dos diferentes atores da sociedade, sob a perspectiva de sujeitos em ação". A gestão social é uma forma de gestão que valoriza a concordância, em que o outro deve ser incluído e a solidariedade é a sua motivação (Maia, 2005; França Filho, 2008). Ademais, a gestão social caracteriza-se por seu caráter coletivo, cujos contornos se delineiam nos processos sociais, relações de poder, conflitos e aprendizagem (Fischer, 2002).

Afinal, a construção de uma iniciativa num determinado território é permeada por diversos fatos, diálogos e eventos inesperados e não lineares que são, na maior parte das vezes, ignorados por boa parte da literatura administrativa tradicional, mas que, por outro lado, estão presentes no que alguns pesquisadores denominam de cidadania deliberativa (Habermas, 2003). Nesse contexto, emerge a cidadania deliberativa como um conceito teórico apropriado, pois a busca por alternativas de solução às demandas locais ocorre por meio do efetivo exercício de direitos e deveres dos atores em seus territórios.

Para efeitos deste artigo, cidadania deliberativa "significa que a legitimidade das decisões políticas deve ter origem em processos de discussão, orientados pelos princípios da inclusão, do pluralismo, da igualdade participativa, da autonomia e do bem comum" (Tenório, 
2005:105). O que se propõe é uma cidadania deliberativa não só no que diz respeito àquelas ações vinculadas ao poder público, mas também àquelas originadas em processos produtivos tanto de agentes econômicos quanto de agentes sociais (Tenório, 2012). Desta forma, estimula-se a participação social e a integração de ações entre os entes federativos, consideradas fundamentais na construção das iniciativas locais (Andion, 2009).

Neste contexto, a abordagem territorial exige, entre outros, a análise institucional em torno da qual se organiza a interação social localizada (Abramovay, 2010). Pensar a gestão do território implica considerar os diferentes padrões de inter-relacionamento ativo dos diversos atores da sociedade (Echeverri, 2010; Abramovay, 2010), preconizando o local e a abordagem bottonup, requerendo ainda o caráter participativo (Echeverri, 2010). Contudo, o enfrentamento dessa problemática envolve necessariamente conflitos de percepção e de interesses entre os atores sociais nas diversas escalas territoriais. Aliás, o conflito é inerente à prática de gestão social, em especial quando o foco é o território (Zani et al., 2012).

O território torna-se, assim, o palco central das dinâmicas de desenvolvimento, ou seja, uma unidade que dispõe de recursos ativos específicos e não transferíveis de uma região para outra (Andion, 2009). São recursos materiais e imateriais, como um saber-fazer, relacionado à história local (Cazella, Bonnal e Malluf, 2009). Assim, a visão do território põe ênfase na maneira como uma sociedade utiliza os recursos de que dispõe em sua organização produtiva e, portanto, na relação entre sistemas sociais e ambientais (Abramovay, 2010).

A recomposição territorial não se faz jamais de forma idêntica em todos os lugares e as estratégias de desenvolvimento não são universais, nem seguem um modelo definido (Andion, 2009); "elas convidam cada localidade ou região, que enfrenta uma situação de declínio, a inventar o seu próprio modelo de reconversão" (Fontan, Klein e Lévesque, 2003 apud Andion, 2009:6).

Para pensar em DTS trata-se de construir projetos de desenvolvimento que respondam às necessidades das comunidades locais, às suas expectativas e que, além disso, se inscrevam harmoniosamente em suas realidades socio-históricas (Jean, 2010), decorrendo de um processo de "construção social". Outrossim, deve-se reconhecer que há muitos projetos e programas, delineados nas instâncias estaduais e federais, que influenciam os governos locais, mas que são incapazes de criar caminhos que permitam um mínimo de competência dialógica. As regras estabelecidas e, também, a falta de reconhecimento dos múltiplos saberes podem gerar ciclos de produção e reprodução da desigualdade e da exclusão social (Iizuka et al., 2011).

O território, portanto, não é apenas uma realidade geográfica ou física, mas uma realidade humana, social, cultural e histórica (Cazella, Bonnal e Malluf, 2009). A figura 1 busca retratar a convergência dos conceitos gestão social, cidadania deliberativa e desenvolvimento territorial sustentável.

A abordagem do DTS, compreendida como um enfoque sistêmico do desenvolvimento, leva em conta a busca de novos instrumentos de política que favoreçam um desenho negociado e contratual de novos projetos de sociedade (Vieira, 2005). Embora prevaleça, no campo das políticas públicas, o tradicional modelo descendente (top-down) em que tecnocratas, 
legitimados pela racionalidade técnica, monopolizam a definição das políticas públicas, os Estados são incitados a progressivamente adotar o modelo ascendente (bottom-up), baseado na interseção da administração pública com a sociedade num processo circular mediado por relações recíprocas de poder e negociação (Saravia, 2009).

Figura 1

A interseção dos conceitos gestão social, cidadania deliberativa e desenvolvimento territorial sustentável

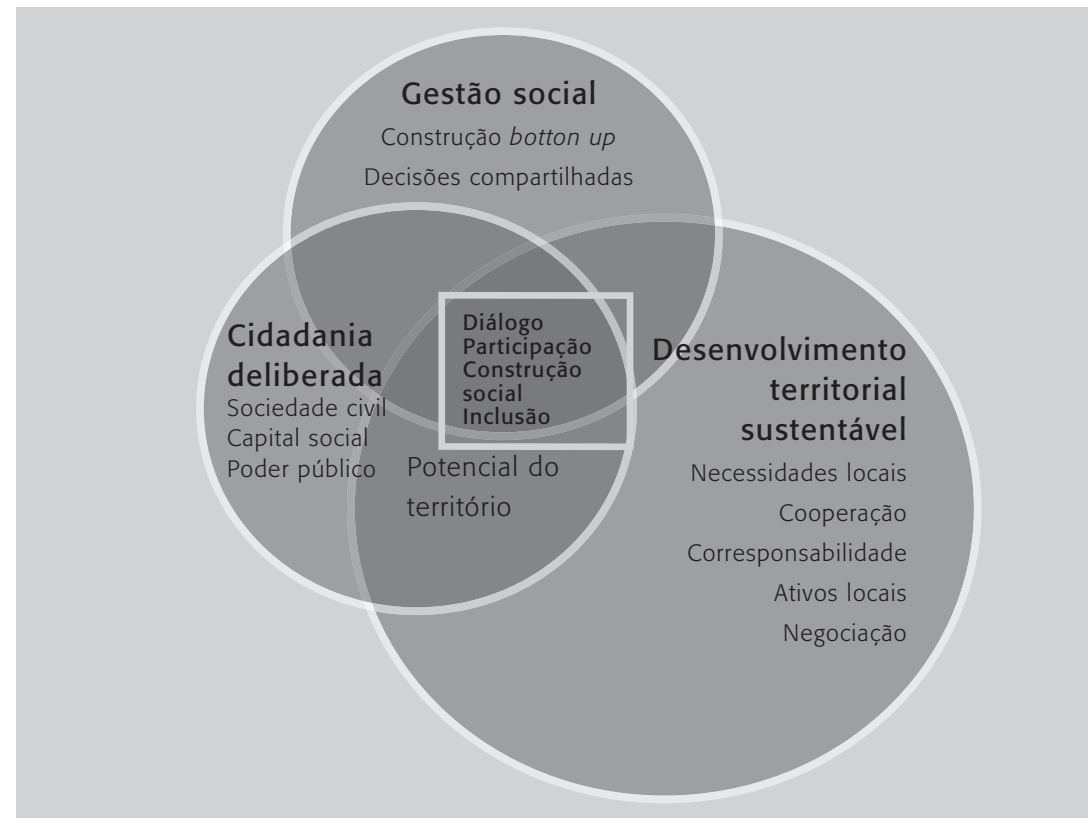

Fonte: Elaborada pelos autores.

Assim, o enfoque territorial implica a transição de uma lógica burocrática e de "balcão" na promoção do desenvolvimento e na gestão das políticas públicas para uma lógica baseada em projetos e que valorize as vocações e os recursos específicos do território (Beduschi Filho e Abramovay, 2004). Neste sentido, o projeto de desenvolvimento deve ser coletivo, envolvendo forças sociais locais, cujo processo é indissociável da ideia de gestão social (Zani, 2012). A seguir, apresenta-se a estratégia metodológica para a investigação do caso do Programa de Manejo Agroambiental da Bacia do Rio Almada (BA).

\section{Procedimentos metodológicos}

Para o desenvolvimento deste estudo, optou-se por uma abordagem exploratória de pesquisa descritivo-qualitativa, na medida em que se trata de uma temática pouco investigada e sobre 
a qual é necessário um aperfeiçoamento na questão de pesquisa. Assim, exigiu-se um esforço inicial na compreensão do território a ser investigado, buscando superar uma visão difusa e multifacetada. Além disso, a pesquisa qualitativa apresentou-se como a mais adequada à problemática de pesquisa e a que permitiu um avanço no entendimento da participação dos diferentes atores no contexto de uma gestão social, da cidadania deliberativa, assim como do desenvolvimento territorial sustentável.

Entre as diversas técnicas de pesquisa qualitativa, o método do estudo de caso constituiu-se na abordagem mais adequada, na medida em que se pretendia uma análise aprofundada sobre atores locais, processo decisório e cidadania deliberativa, buscando aprimorar o entendimento da gestão social em um território, o que implicou conhecer o contexto específico de manifestação do fenômeno (Vergara, 2005). Procedeu-se então à análise da construção e implementação do "Programa de Manejo Agroambiental da Bacia do Rio Almada" na região do Litoral Sul da Bahia.

Assim, organizaram-se os dados, as informações e as entrevistas por meio de estudo de caso. Para análise do caso, foi utilizada a triangulação de técnicas da história oral (Verena, 2004; Berg, 2004; Cassab, 2003) e do sensemaking (Weick, 1995). Essa forma de investigação permitiu uma análise longitudinal sobre a participação dos diferentes atores sob a ótica da gestão social, assim como da cidadania deliberativa, contextualizadas num determinado território. A construção do estudo foi realizada em três etapas, conforme segue.

\subsection{Primeira etapa: seleção do caso e levantamento dos dados}

A primeira etapa ocorreu entre 2004 e 2008, em que se realizaram a revisão bibliográfica, a seleção do caso, a coleta de dados primários e secundários e a análise preliminar dos dados. Para seleção do caso, procedeu-se à busca e análise dos 34 projetos e programas desenvolvidos em pequenos municípios brasileiros, premiados pelo Programa Gestão Pública e Cidadania da FGV-Eaesp entre os anos de 1996 e 2005. Foi selecionada a experiência inovadora do Programa de Manejo Agroambiental da Bacia do Rio Almada, levando-se em consideração os seguintes aspectos: o grau de complexidade do projeto ou programa, os fluxos de ações, a localização geográfica em território da cidadania. A partir disso foram feitas análises documentais do projeto e de outros insumos como a ficha de inscrição da experiência e o relatório de campo elaborado pelos pesquisadores da FGV-Eaesp sobre o caso. Foram realizadas 11 entrevistas em profundidade com pessoas que participaram ou que testemunharam acontecimentos e conjunturas do passado, e também do presente. No quadro 1 apresenta-se a caracterização dos atores entrevistados, preservando sua identidade.

As entrevistas foram gravadas, transcritas literalmente e codificadas para garantir o anonimato dos entrevistados. Construiu-se relatório de campo a partir do registro das visões e percepções do ocorrido dos principais atores que participaram da construção e implementação da experiência. As ideias principais que emergiram das entrevistas foram checadas com mais de um entrevistado, evitando-se, assim, a mera opinião, buscando-se desta forma a validade do registro obtido (Verena, 2004; Cassab, 2003). 
Quadro 1

\section{Caracterização dos entrevistados}

\begin{tabular}{|c|c|c|c|}
\hline Atores & Grupo & Código & Característica \\
\hline $\begin{array}{l}\text { Comunidade } \\
\text { local }\end{array}$ & $\begin{array}{l}\text { Moradores da } \\
\text { nascente do rio } \\
\text { Almada }\end{array}$ & $\begin{array}{l}\text { Morador } 1 \\
\text { Morador } 2 \\
\text { Morador } 3 \\
\text { Morador } 4\end{array}$ & $\begin{array}{l}\text { Os moradores da nascente do rio Almadina (BA) } \\
\text { vivem numa região isolada, de difícil acesso, foram } \\
\text { ignorados, num primeiro momento, pelo Programa do } \\
\text { Manejo Agroambiental da Bacia do Rio Almada. }\end{array}$ \\
\hline \multirow[t]{2}{*}{ Poder público } & $\begin{array}{l}\text { Poder público } \\
\text { local (Executivo e } \\
\text { Legislativo) }\end{array}$ & Executiva 1 & $\begin{array}{l}\text { A ex-prefeita de Almadina teve uma participação } \\
\text { marcante na elaboração do Programa, apresentando-se } \\
\text { como uma liderança local relevante. Contudo, em } \\
\text { função da dinâmica política, ela foi expulsa da } \\
\text { prefeitura pelos seus adversários e mudou-se para } \\
\text { Salvador. }\end{array}$ \\
\hline & & Vereador 1 & $\begin{array}{l}\text { Ex-vereador de Coaraci (BA) foi um dos articuladores } \\
\text { da proposta no município que fazia parte do Programa } \\
\text { de Almadina }\end{array}$ \\
\hline \multirow[t]{5}{*}{$\begin{array}{l}\text { Organizações } \\
\text { da sociedade } \\
\text { civil }\end{array}$} & $\begin{array}{l}\text { Sindicato Pequenos } \\
\text { Produtores Rurais } \\
\text { Almadina e Região }\end{array}$ & Membro do Sindicato & $\begin{array}{l}\text { Pouco participou da elaboração do Programa. } \\
\text { Contudo, foi fundamental para a compreensão das } \\
\text { limitações da proposta, contextualizando os erros } \\
\text { cometidos, sob o ponto de vista dos pequenos } \\
\text { produtores rurais. }\end{array}$ \\
\hline & $\begin{array}{l}\text { Movimento Social } \\
\text { do Território da } \\
\text { Cidadania do Sul da } \\
\text { Bahia }\end{array}$ & Ativista social & $\begin{array}{l}\text { Sem envolvimento com a elaboração do Programa. } \\
\text { Entretanto, trata-se de uma pessoa relevante para } \\
\text { a compreensão do território e o processo histórico, } \\
\text { pois faz parte de uma família que há décadas atua na } \\
\text { região. }\end{array}$ \\
\hline & ONG Grama & Coordenador da ONG & $\begin{array}{l}\text { Participou da elaboração do Programa e reconheceu o } \\
\text { erro em não dialogar com a comunidade local. }\end{array}$ \\
\hline & $\begin{array}{l}\text { Sindicato Patronal } \\
\text { Produtores de } \\
\text { Cacau do Sul da } \\
\text { Bahia }\end{array}$ & $\begin{array}{l}\text { Presidente do } \\
\text { Sindicato Patronal }\end{array}$ & $\begin{array}{l}\text { Um dos principais articuladores e ativistas do } \\
\text { Programa. Atuação destacada na elaboração da } \\
\text { proposta, especialmente na articulação dos poderes } \\
\text { locais (Executivo e Legislativo - poder público; } \\
\text { universidade - técnicos e pesquisadores). }\end{array}$ \\
\hline & $\begin{array}{l}\text { Coordenador geral } \\
\text { do programa }\end{array}$ & Técnico & $\begin{array}{l}\text { Jornalista contratado para coordenar o programa e } \\
\text { principal responsável pela implantação do Programa } \\
\text { em Almadina. Principal articulador das organizações } \\
\text { participantes. Pessoa-chave para a compreensão } \\
\text { do processo de elaboração e, principalmente, } \\
\text { implantação da iniciativa. }\end{array}$ \\
\hline
\end{tabular}

Fonte: Elaborado pelos autores. 


\subsection{A segunda etapa: análise dos dados e fatos}

A segunda etapa aconteceu entre 2010 e 2011, quando se empreenderam as análises sob a ótica da gestão social e cidadania deliberativa a partir da atuação dos diferentes atores. Num primeiro momento, no que se refere à análise de dados sob esse prisma, foram utilizadas as categorias analíticas de acordo com cinco dimensões: cidadania, poder público, sociedade civil, potencial do território e capital social (Tenório, 2004). Essa mesma ênfase analítica foi utilizada em pesquisa acerca da experiência do manejo sustentável da samambaia silvestre no município de ilha Comprida, pertencente ao território da cidadania do vale do Ribeira (SP) (Iizuka et al., 2011).

\subsection{A terceira etapa: uma releitura dos dados e fatos}

Finalmente, entre 2011-2012, desenvolveu-se um esforço adicional de reflexão sobre o desenvolvimento territorial sustentável. Essa etapa consistiu numa releitura da pesquisa e exigiu retorno à literatura e ao campo, além de provocar debates dos autores em eventos e fóruns acadêmicos. Como método de pesquisa, utilizou-se o sensemaking (Weick, 1995) nas análises retrospectivas, sobretudo nas reflexões acerca do desenvolvimento territorial sustentável.

Nesta etapa da pesquisa, buscou-se contribuir com novas reflexões no campo das políticas públicas que estão se desenvolvendo em diferentes territórios no país, sob a perspectiva do DTS. Igualmente, verificou-se uma convergência conceitual entre a gestão social, a cidadania deliberativa e o desenvolvimento territorial sustentável. Diante disso, para viabilizar as análises teóricas e empíricas, foram utilizadas as seguintes categorias que emergiram da revisão da literatura:

- Diálogo: trata-se da noção dos sujeitos comunicativos, atuantes em seus contextos, sendo capazes de transformá-lo (Freire, 2005; Habermas, 1987). A participação de distintos atores em diferentes momentos - idealização, construção, implantação e avaliação de uma política pública - ocorre em meio a discussões, debates, conversas, em assembleias gerais, assim como em pequenos grupos;

- Construção social: pensar o contexto local como uma construção social complexa e difícil (Berger e Luckman, 2002), "uma construção suscetível de variar consideravelmente no tempo, segundo os grupos envolvidos e os paradigmas sociais predominantes" (Levesque, 2007:58). Mais do que técnicas e instrumentos rebuscados, as experiências recentes em territórios têm valorizado a ideia de se construírem soluções a partir das pessoas, desde a discussão sobre as reais demandas que emergem da sua situação vivida, até o processo de implantação. Ou seja, de acordo com cada realidade, e sem soluções "padrão" impostas a priori, trabalha-se a partir dos anseios, necessidades e expectativas que dinamicamente se combinam num processo de construção coletiva; 
- Participação: refere-se ao pluralismo, no qual conta-se com múltiplos agentes de organização da participação social; combina-se a ampliação da cidadania e a construção coletiva de processos políticos (Gohn, 2003; Nogueira, 2004). A participação social deriva da concepção de cidadania ativa, implicando colocar a decisão em debate (Milani, 2008). Diante de visões distintas e difusas sobre o território, assim como dos caminhos e alternativas para se alcançar o desenvolvimento social, econômico e ambiental, resulta um cenário em que emergem debates, conflitos e, às vezes, consensos, e que, portanto, favorecem processos decisórios cada vez mais participativos;

— Inclusão: estudos reforçam a tese de que o excluído não está à margem da sociedade, mas repõe e sustenta a ordem social, sofrendo muito no processo de inclusão social (Sawaia, 1999; Castel, 1998). Neste contexto, o reconhecimento de diferentes atores, sobretudo aqueles que historicamente foram excluídos das políticas públicas, seja como beneficiários, seja como participantes na construção de soluções, passam a ser reconhecidos. Afinal, as potencialidades e fragilidades num determinado território passam pelas pessoas que nele vivem.

A seguir apresentam-se os resultados e a discussão do caso ocorrido na bacia hidrográfica do rio Almada.

\section{Caracterização da bacia hidrográfica do rio Almada}

Situada na região sul da Bahia, a bacia hidrográfica do rio Almada ocupa uma área de 1.670 $\mathrm{km}^{2}$ e abrange os municípios de Almadina, Coaraci, Ibicaraí, Itabuna, Itajuípe, Lomanto Júnior, Uruçuca e Ilhéus. Área de predomínio do bioma Mata Atlântica, tem tido no cultivo de cacau, historicamente, sua atividade econômica mais importante, notabilizando particularmente Itabuna e Ilhéus. É no município de Almadina que se localiza a nascente do rio Almada, que percorre os municípios anteriormente citados.

A referida bacia está situada no Território da Cidadania Litoral Sul, que abrange 26 municípios. ${ }^{3}$ O Território Litoral Sul tem população de 772.694 habitantes, dos quais 139.828 residem na área rural (18\% do total). Essa região apresenta baixa densidade demográfica, oscilando em torno de 50 hab. $/ \mathrm{km}^{2}$, exceção feita a Itabuna (473 hab./ $\mathrm{km}^{2}$ ). Sua dinâmica populacional nas últimas décadas foi de redução populacional, que atingiu municípios da bacia como Almadina, Ibicaraí, Coaraci e Itajuípe (IBGE, 2010). Cerca de 80\% dos habitantes da bacia residem na área urbana. Na figura 2 pode-se visualizar a localização da bacia hidrográfica do rio Almada, dentro do território sul baiano.

\footnotetext{
${ }^{3}$ São eles: Almadina, Arataca, Aurelino Leal, Barro Preto, Buerarema, Camacan, Canavieiras, Coaraci, Floresta Azul, Ibicaraí, Ilhéus, Itabuna, Itacaré, Itaju do Colônia, Itajuípe, Itapé, Itapitanga, Jussari, Maraú, Mascote, Pau Brasil, Santa Luzia, São José da Vitória, Ubaitaba, Una e Uruçuca (Brasil, 2009).
} 
Figura 2

\section{Localização da bacia hidrográfica do rio Almada (BA)}

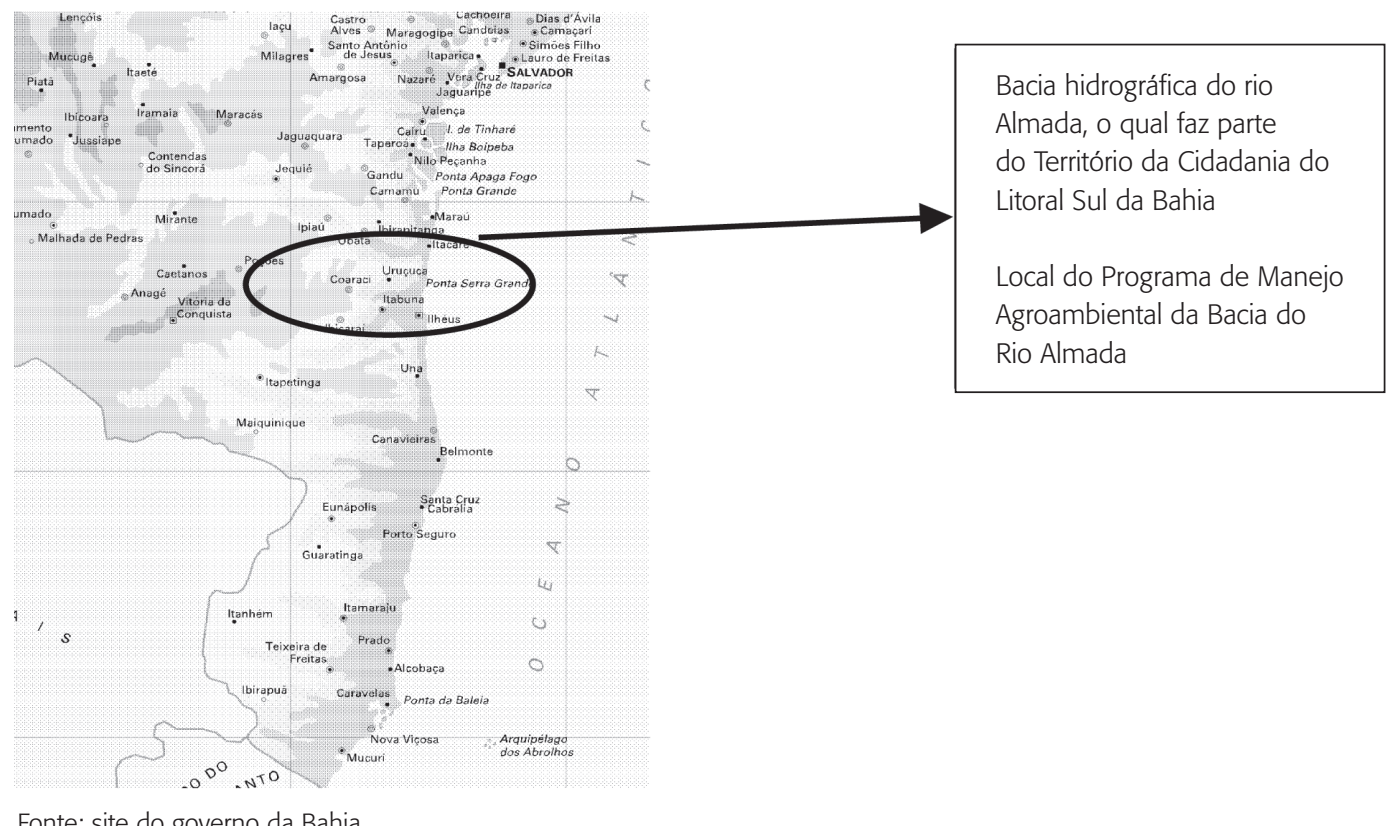

Contabilizam-se atualmente 13.929 agricultores familiares, 2.330 famílias assentadas, 13 comunidades quilombolas e duas terras indígenas. Seu IDH médio é 0,67, bastante abaixo do IDH médio brasileiro, que é de 0,72 (Brasil, 2009). Conta com “organização social (sindicatos, associações, cooperativas, movimentos sociais de luta pela terra) forte, contrapondo a uma elite retrógrada, coronelista e conservadora" (Brasil, 2007:4). O contexto histórico da região incluiu uma série de problemas concomitantes nas décadas de 1980 e 1990, com impactos consideráveis na região, entre os quais: dificuldade de acesso a crédito no sistema financeiro, redução dos preços internacionais do cacau, ocorrência de estiagens e o aparecimento da vassoura-de-bruxa (May e Rocha, 1998).

No início da década de 1990, houve uma forte infestação da "vassoura-de-bruxa" causada pelo fungo Clinipellis perniciosa. Desde então, a região vem passando por um processo de transformações. As lavouras, que antes tinham caráter conservacionista a partir da cabruca (cacaueiro cultivado à sombra de árvores nativas), foram cedendo lugar ao desmatamento e ao uso intensivo de agroquímicos, ocasionando desequilíbrio ecológico, perda da biodiversidade, assim como a contaminação dos cursos d'água pelo lançamento de efluentes (Brasil, 2006). Seguiu-se então um momento de intensa pressão sobre as áreas remanescentes de Mata Atlântica com a implantação de pastagens, monoculturas agrícolas, extração de madeira ilegal e plantações de eucalipto, só superada no final dos anos 1990, com nova valorização do preço internacional do cacau e a retomada desta cultura no sul da Bahia. 
Entretanto, uma relevante peculiaridade histórica do território da bacia é a preservação de boa parte da Mata Atlântica, devido ao predomínio do cultivo tradicional do cacau pelo sistema cabruca, que se caracteriza pela "manutenção da estrutura florestal, para sombreamento" (May e Rocha, 1998:47), ${ }^{4}$ favorecido pelo solo fértil, abundância de água e clima favorável não só para esse produto como também para culturas como mandioca, guaraná, pupunha, frutas e especiarias.

\subsection{0 processo de construção do Programa de Manejo Agroambiental da Bacia do Rio Almada (1996-98)}

A proposta denominada "Programa de Manejo Agroambiental da Bacia do Rio Almada" foi formulada em 1996. A iniciativa chamava a atenção pela ousadia na proposta de transformação social, política, econômica e cultural, evidenciando um projeto de desenvolvimento territorial sustentável, por meio do cultivo do cacau cabruca, que tinha suas raízes no conhecimento tradicional local (saber popular). Em síntese, o Programa empreendido em Almadina foi descrito por Fernandes (1999:2) da seguinte forma:

com o objetivo geral de criar alternativas econômicas para a região, que respondam a critérios de preservação da Mata Atlântica e da biodiversidade, técnicos da Central Nacional dos Produtores de Cacau — CNPC, da Comissão Executiva do Plano da Lavoura Cacaueira — Ceplac e da organização não governamental Grupo de Resistência às Agressões do Meio Ambiente — Grama reuniram-se em torno da elaboração de um projeto de desenvolvimento agrícola sustentável para região cacaueira.

Em 1996, este grupo encaminhou ao Programa Nacional de Meio Ambiente/Projetos de Execução Descentralizada (PNMA/PED), realizado pelo Ministério do Meio Ambiente, dos Recursos Hídricos e da Amazônia Legal, em convênio com o Banco Internacional para Reconstrução e Desenvolvimento (Bird), um projeto de captação de recursos, que concorreu com 13 outros no estado da Bahia e conseguiu aprovação, de R\$ 1.232.484,00, para o desenvolvimento do "Programa de Manejo Agroambiental da Bacia do Rio Almada" (Fernandes, 1999). Naquela época, esse programa foi gerenciado pela CNPC, Grama e Ceplac, e contou com a participação de cerca de 30 profissionais. Sua gestão e execução foram feitas por meio de um consórcio, no qual participaram os municípios de Almadina (gestor), Coaraci e Uruçuca (coexecutores). A operacionalização do Programa se deu a partir de três frentes, conforme apresentou Fernandes (1999):

\footnotetext{
4 “(...) esse sistema adquire a função conservacionista, atuando como buffer zone (zona tampão) às áreas protegidas da Mata Atlântica. (...) O sistema cabruca também se mostra eficiente como corredor de várias espécies de aves e mamíferos entre manchas de florestas remanescentes" (May e Rocha, 1998:47).
} 
— implantação de agricultura diversificada por meio da aplicação prática dos conceitos e técnicas de sistemas agroflorestais (SAF);

— fomento à criação de associações produtivas e agroindústrias visando ao desenvolvimento econômico, a partir da alocação e distribuição do produto agrícola gerado;

- promoção de atividades de conscientização, educação ambiental e capacitação técnica dos pequenos produtores envolvidos, a partir de treinamentos e minicursos.

O público beneficiário imediato e direto considerado eram pequenas comunidades agrícolas, pequenos produtores rurais, estudantes e organizações comunitárias (Fernandes, 1999).

Em complemento às análises documentais, a visita de campo e as entrevistas permitiram emergir novos elementos do processo de construção do Programa em Almadina.

Considerando o momento em que foi concebido e buscando atribuir sentido às práticas desenvolvidas, um dos coordenadores do Programa o retratou da forma seguinte:

(era) como se a gente estivesse numa encruzilhada sem saída para lugar nenhum e de repente pinta algumas ideias e a gente coloca essas ideias no papel (...). O projeto foi cobaia de nós próprios, talvez tenha sido um certo desespero naquele momento terrível de falência total em tudo: falência profissional, falência política, falência econômica, falência cultural. Estão pedindo a solução para a gente, tem dinheiro para a gente propor a solução (...) Vamos criar associações, sim, mas as associações não estão criadas, nós temos três ou quatro meses para começar a trabalhar com associação (Presidente do sindicato patronal).

Para elaborar a proposta da bacia do rio Almada em curto espaço de tempo, reuniramse acadêmicos, técnicos e especialistas de diversas áreas. Esse grupo de pessoas foi assim caracterizado pelo presidente do sindicato dos produtores rurais: “(...) nós tínhamos muita técnica, muito conhecimento tanto teórico como prático (...) tudo era intuitivo, todos tinham intuição, nós éramos únicos naquela época" (Presidente do sindicato patronal). Um exemplo do raciocínio utilizado na época, que ilustra, em parte, a lógica empregada pelo grupo, está presente na declaração feita por um dos participantes do Programa:

(...) a usina de leite de Almadina era perfeita na concepção [grifo nosso], ou seja, um município produtor de leite, o prefeito se dispôs a comprar a metade da produção para aplicar na merenda escolar e o governo do estado e o governo federal deu o maquinário e a construção física e simplesmente eles não tiveram capacidade de um ano, um ano e meio fomentar um espírito de que reunidos eles teriam lucro ou poderiam ter alguma coisa maior (Membro do sindicato).

Diversas declarações confirmaram que o Programa foi concebido por um grupo restrito de pessoas. O processo decisório, portanto, apesar de um projeto tecnicamente bem fundamentado, ocorreu de forma isolada, de "cima para baixo". E a declaração feita pelo presidente do sindicato dos produtores rurais, um dos membros mais ativos na construção do Programa, que foi compartilhada por outros entrevistados como o participante de uma ONG ambien- 
talista, um associado do sindicato dos trabalhadores rurais, um morador da nascente do rio Almada e um dos coordenadores do Programa.

A maneira verticalizada de tomada de decisão não trouxe problemas na formulação da proposta, o projeto foi escrito e bem estabelecido sob o aspecto técnico, mas, conforme as palavras de um dos membros do sindicato dos trabalhadores rurais:

(...) o importante não é você botar o projeto no papel, o importante é você executar o projeto (...) a coisa veio de cima para baixo [grifo nosso], o projeto veio sem uma preparação da base que ia trabalhar o projeto (...) qualquer trabalho que você caminhe você tem que ter uma base para tocar aquele projeto. E a base tanto em Almadina como em Coaraci não existiu, para mim foi a grande falha do projeto [grifo nosso], o projeto foi muito bonito, muito bem elaborado, mas no papel, pois na prática... (Membro do sindicato).

Por outro lado, a não participação da comunidade no Programa, especialmente na sua concepção, não pareceu ser algo deliberado e em que houvesse más intenções, mas que gerou importantes aprendizados quanto à importância do saber da comunidade, conforme afirmou um membro da ONG ambientalista:

(...) criar associações num momento assim emergencial, para assumir a gestão, por exemplo, de uma usina de beneficiamento de leite (...) talvez tenha até tido a boa intenção em ajudar aquela comunidade, os pecuaristas das cidades envolvidos no projeto, mas não se discutiu antes com a parte interessada e aí infelizmente se investiu muito dinheiro na compra de equipamentos caríssimos e que está obsoleto lá, fechado, então a gente não pode estar mais errando dessa forma, a gente tem hoje lições, várias lições, que nos levam para cada vez mais aperfeiçoar, respeitando justamente o conhecimento, a experiência da comunidade, nós não podemos nunca pensar pela comunidade, nós temos que pensar junto com a comunidade [grifos nossos] (Técnico).

O argumento do receio de ouvir a comunidade e de que ela não teria maturidade para um diálogo fica fragilizado, como mostra uma declaração feita por um dos moradores da nascente do Rio Almada:

(...) esse projeto do Almada que era um projeto que nem podia ficar na minha mão porque envolvia Almadina, Coaraci e Uruçuca. Três cidades que o rio Almada abastece. Então não tinha nem condição desse projeto ficar na minha mão (...) Tinha que ter uma pessoa para resolver esse lado, mas que a gente tivesse condição de ver o que tinha no projeto (Morador 2).

Esse morador, portanto, demonstrou seu discernimento quanto aos seus limites para coordenar e conduzir um projeto, mas nem por isso acreditava que deveria ficar alienado no processo.

Em síntese, depreende-se, em consonância com Tenório (2012:29), que uma gestão social é "a relação entre pessoas e não uma ação para pessoas". Sob esta ótica não caberia 
uma conexão instrumental, mas sim cooperada, solidária ou negociada entre os envolvidos na ação. O processo inicial de construção do Programa contou com a participação apenas parcial de atores, tais como técnicos, acadêmicos, membros de sindicatos e ONGs. O Programa foi escrito para essa parcela da população e não com estas pessoas, ou seja, a inclusão de novos atores, sobretudo os mais pobres e excluídos, ocorreria apenas como resultado e não como premissa ou, ao menos, durante o processo de construção desta experiência. Assim, nesse momento, os diálogos, e a consequente construção social do Programa, ocorreram de forma limitada.

\subsection{O Processo de implementação e os resultados do Programa do Manejo Agroambiental da Bacia do Rio Almada}

Diante da forma como foi construído, não foi estranho que durante todo o processo de implantação do Programa, e mesmo após esse período, diversas acusações, dúvidas e questionamentos emergiram. E foi isso que o membro da ONG ambientalista relembrou:

(...) acredito que seja por isso que gerou polêmica, foi por isso que gerou várias discussões, insatisfações, por não compreender o projeto como um todo porque a base da comunidade não participou da discussão [grifo nosso], da construção do projeto, infelizmente esse projeto teve o seu prazo, ele cumpriu o prazo com roteiros e os recursos que foram alocados para financiar o projeto, ele encerrou, mas tivemos assim um resultado que não foi muito bom (Coordenador da ONG).

Um sindicalista relembrou que o projeto inicial não havia contemplado alguns aspectos fundamentais para seu funcionamento, reforçando o argumento acerca do saber prático de quem implementa os projetos:

(...) a gente vê uma fábrica de polpa que era para ser montada. Fizeram a câmara, mas não se concluiu a obra. (...) Não se pensou em água (...) basta a gente dizer que para lavar 500 caixas de cajá, uma fruta que vem da roça, cai no chão, a gente precisa nada mais nada menos que uns 5 mil litros de água, e não se pensou nisso. E o consumo da água, não foi previsto. (...) Você tem que armazenar, como você não tinha as câmaras prontas como é que você ia armazenar o produto? Não se pensou em um pasteurizador. Não se projetou um dosador automático. Não se projetou um tanque de lavagem. Que fábrica é essa? (Membro do sindicato).

Em alguns episódios, contudo, diante do processo de formulação e implantação, parece que a solução existia antes do problema. Um dos coordenadores confirmou a criação da fábrica de polpas antes que houvesse a clareza do problema a ser resolvido, mas reconhecendo que havia certo sentido naquela ação: 
(...) não tem como fazer a fábrica antes como foi feito. O problema é o seguinte: a ansiedade de vir acontecer alguma coisa nova (...) de ter que responder ao edital nesses dois meses. Para fazer a proposta em um ano e meio criou esse tipo de loucura, já então você tinha que comprar cinco carros, um caminhão para buscar as frutas, uma fábrica para produzir as frutas. E, o essencial, o básico, as pessoas que vão fazer [produzir] as frutas não estavam preparadas. Não estavam amadurecidas para o processo (...) Não é que a proposta estivesse errada. Ela não teve tempo de ser maturada pelas pessoas, as pessoas não tinham capacidade de maturação naquela época [grifos nossos] (Técnico).

Analisando-se retrospectivamente, um projeto que de certa forma fez sentido no passado parecia estar, na realidade, pouco sintonizado com a realidade daquele momento, tal como foi lembrado por um dos coordenadores: “(...) naquela época o projeto foi muito idealista, muito revolucionário (...) acho que o projeto hoje estaria esse mesmo projeto, estaria mais adequado para a realidade de hoje" (Técnico).

Por outro lado, esse coordenador reconheceu que os erros cometidos em relação ao que foi inicialmente planejado propiciaram resultados inesperados e, em certo sentido, positivos: "mas ao mesmo tempo de fazer e não dar certo, na maioria dos casos, provocou com que esses grupos começassem a pelo menos saber que 'bom, isso aqui não vai', tanto que [d] as associações presentes no projeto a única que deu certo foi a da nascente do Almada e não estava previsto" (Técnico).

Um morador da nascente do rio Almada, em sua avaliação do processo, reconheceu que o Programa teve suas limitações, mas trouxe benefícios, ou seja, sob esse ponto de vista foi válido e útil para a comunidade, pois, conforme as suas palavras:

(...) de certa forma ajudou a gente, não posso dizer que esse projeto não ajudou na região não porque ajudou. Foi feita muita coisa (...) Foi feito um SAF direto, isso aqui foi tudo plantado, plantamos muitas mudas aqui, um plantio de graviola, plantamos esses cocos, foi construída essa casa aqui (...) Quando você tem um projeto às vezes entra política pelo meio e daí acaba com um projeto trazendo outro, então esse projeto da Care foi um projeto separado, foi executado pela gente mesmo da associação (...) Fizemos o plantio, fizemos esse ponto de apoio aqui tipo uma cozinha. Aí já veio os banheiros para todas as casas, fossa. Isso aí foi doação da Fundação Nacional da Saúde (...) Eu mesmo fui muito beneficiado porque eu não tinha casa, eu morava num barraquinho ali (Morador 1).

Assim, ainda que o Programa original não tenha alcançado os resultados pretendidos, sua existência fez sentido como tentativa para melhorar as condições de vida dos moradores da nascente do rio Almada, ainda que determinadas ações não estivessem relacionadas à proposta original; mas isso, no entender do morador, foi o que abriu as portas para outras ações, muitas vezes ligadas a questões de saneamento básico. Essa opinião foi compartilhada por um membro de uma ONG ambientalista que participou do processo de implantação. 
E o coordenador relembrou algumas surpresas positivas que ocorreram mesmo após a implantação do Programa, buscando confrontar as expectativas iniciais e os acontecimentos que emergiram no fluxo de ações:

(...) ele (presidente da associação de moradores) começou a desencavar outras alternativas que não as que nós apresentamos que deram certo lá em cima. Lá não tinha energia que ele conseguiu depois do projeto. Aqueles sanitários nos fundos das casas, se você observou, deve ter ainda, a casa é de taipa e o sanitário é de cimento, aquilo foi feito conosco. Mas não foi o projeto, foi outra coisa que a gente conseguiu levar para lá (Técnico).

E, neste contexto, relatou um fluxo de ações contínuo e condizente com os anseios da população local, tal como disse um dos coordenadores do Programa:

(...) já que o princípio era o coletivo, o princípio era o trabalho de base. Então a base foi naturalmente acontecendo. E foi tirando aquilo que não dava certo e mantendo aquilo. Eu creio que o processo ainda não acabou. Esse processo, esse caldeirão, ainda continua. Claro, hoje, com mais definições, com mais clareza. E talvez seja isso o tempero da vida da gente (Técnico).

Essa consideração, assim, reforça o sentido e a importância da comunidade em projetos e programas, e, além disso, quando isso não acontece, a própria comunidade se organiza e trabalha em busca de seus objetivos, abrindo caminhos, interrompendo outros, num processo que não tem um começo e nem um fim claros. E esse fluxo de ações é permeado pela política, ora sendo estimulado, ora sendo reprimido. Os opositores mais ferrenhos da proposta, de acordo com a consideração do presidente do sindicato de produtores rurais, foram "os grandes produtores e o governo, que é conservador".

Para esse coordenador, a escolha da prefeitura de Almadina como gestora do Programa foi um dos fatores que contribuíram para as dificuldades de implantação, conforme suas palavras: "(...) entrou terceiro setor, entrou o sindicato Patronal, entrou associações ligadas a questões agrícolas, à da nascente e entrou as prefeituras, o que eu acho que travou muito foi essa coisa da Prefeitura estar administrando o projeto com tantas rivalidades políticas interferindo no processo de execução" (Técnico). Para ilustrar sua linha de argumentação, esse coordenador relembrou o seguinte:

(...) a concepção do projeto Almada contou com a participação muito clara, muito constante da prefeita. A então prefeita de Almadina conseguiu agilizar toda a documentação (...) Então apesar de ser muito pequenininho — dez mil habitantes — mas é um município representativo porque é lá que nasce o rio Almada, um motivo simbólico. Enquanto que nos outros municípios não houve um empenho tão grande (...) Só que ela tinha um adversário político considerado forte e habilidoso. Ele conseguiu de alguma forma atravancar o processo inicial do próprio projeto através dos vereadores que eram a favor dele (...). Quando houve a eleição (...) ela não conseguiu a reeleição 
(...). Ela foi literalmente expulsa da cidade e numa situação de tamanho desprestígio, também orquestrado por seu opositor. Quando ela se preparava para mudar da cidade, o caminhão de mudança dela foi saqueado por parte da população. Ela foi para Salvador, foi uma coisa muito triste, ela ficou inclusive traumatizada (Técnico).

Por outro lado, uma das ativistas mais conhecidas na região de Coaraci, Almadina, Uruçuca, Itajuípe (litoral sul baiano), numa palestra com pequenos agricultores relembra um processo que vem acontecendo nessa região e que parece apontar para uma nova dinâmica política em construção:

(...) as pessoas não estavam aqui paradas. Infelizmente não havia apoio para elas. Não havia um olhar para aquilo que elas estavam querendo e hoje já existe esse olhar (...) que as coisas não aconteçam mais de cima para baixo. Que o deputado A ou o deputado B, que o governador Y ou o presidente $\mathrm{Z}$ que vai dizer, vai ser assim em Coaraci, vai ser assim em Almadina. Que a sociedade, a comunidade que vai definir coletivamente como é que deve ser porque a gente sabe que vai ser o João, mas a gente não sabe quem é o João, a gente tem o nome de Maria, mas a gente não sabe nem quem é Maria. Chegou aí um elefante branco que a gente nem sabe para onde é e nem como vai funcionar. Isso acabou, eu acredito (Ativista social).

O contexto político em Almadina e região emergiu como um dos fatores que comprometeram, provavelmente, a implantação do Programa. Por outro lado, parece que a política local vem se alterado lentamente.

\subsection{Políticas no (e para o) território sul baiano: convergências ou divergências?}

Diante disso, pode-se argumentar que o momento de implementação e alcance dos primeiros resultados, que ficaram aquém do esperado, mas que abriu portas para iniciativas não planejadas - foi um processo não linear. Os diálogos ocorreram, de maneira paulatina, em função das dificuldades de implementação, ou seja, os moradores e pequenos produtores foram ouvidos apenas após o início da experiência. A inclusão da população mais pobre e excluída foi ocorrendo conforme os rumos tomados pelo projeto. Num período mais recente, foi possível perceber que a participação social tem se fortalecido neste território, de tal forma que a construção social tem ocorrido, cada vez mais, de "baixo para cima", em oposição às práticas top-down.

Após percorrer o processo de construção, implementação, os resultados alcançados e buscando uma análise retrospectiva do Programa de Manejo Agroambiental da Bacia do Rio Almada, apresenta-se o quadro 2 com uma síntese da análise longitudinal do caso a partir das categorias de análise anteriormente definidas. 
Quadro 2

\section{Síntese das categorias conceituais de análise do Programa de Manejo Agroambiental do Rio Almada}

\begin{tabular}{|c|c|c|c|c|}
\hline & $\begin{array}{c}\text { Construção } \\
\text { 1996-97 }\end{array}$ & $\begin{array}{c}\text { Implementação e } \\
\text { primeiros resultados } \\
1998-2000\end{array}$ & $\begin{array}{l}\text { Pós-implementação } \\
\text { 2008-11 }\end{array}$ & $\begin{array}{l}\text { Análise retrospectiva } \\
2012\end{array}$ \\
\hline Diálogo & $\begin{array}{l}\text { Foi parcial, na medida } \\
\text { em que não ocorreu } \\
\text { a participação dos } \\
\text { segmentos populacionais } \\
\text { pobres e excluídos. }\end{array}$ & $\begin{array}{l}\text { Diante das dificuldades } \\
\text { iniciais percebeu-se que a } \\
\text { falta de diálogo e a ausência } \\
\text { na busca de consensos } \\
\text { praticamente impediam a } \\
\text { concretização das propostas } \\
\text { planejadas. }\end{array}$ & $\begin{array}{l}\text { Passados } 10 \text { anos, foi } \\
\text { possível verificar uma } \\
\text { dinâmica de conversas } \\
\text { neste território, no qual } \\
\text { o diálogo e a busca de } \\
\text { consensos têm sido } \\
\text { praticados. }\end{array}$ & $\begin{array}{l}\text { As discussões acerca } \\
\text { dos assuntos relativos } \\
\text { ao DTS neste território } \\
\text { têm sido permeadas } \\
\text { por diálogos e a } \\
\text { busca de consensos } \\
\text { possíveis. }\end{array}$ \\
\hline $\begin{array}{l}\text { Construção } \\
\text { social }\end{array}$ & $\begin{array}{l}\text { A construção social } \\
\text { foi parcial, pois incluiu } \\
\text { somente dirigentes, } \\
\text { técnicos, acadêmicos e } \\
\text { autoridades públicas. }\end{array}$ & $\begin{array}{l}\text { A lógica top-down } \\
\text { demonstrou-se ineficaz } \\
\text { diante da realidade dos } \\
\text { fatos. }\end{array}$ & $\begin{array}{l}\text { Os atores perceberam } \\
\text { que a busca por soluções } \\
\text { está relacionada à maneira } \\
\text { como são construídas. }\end{array}$ & $\begin{array}{l}\text { Os atores } \\
\text { reconhecem-se } \\
\text { mutuamente em torno } \\
\text { dos seus anseios } \\
\text { e buscam, cada } \\
\text { vez mais, construir } \\
\text { soluções de forma } \\
\text { coletiva. }\end{array}$ \\
\hline Participação & $\begin{array}{l}\text { Não, especialmente em } \\
\text { função do prazo exíguo } \\
\text { para atender ao Edital } \\
\text { do Ministério do Meio } \\
\text { Ambiente. }\end{array}$ & $\begin{array}{l}\text { Somente a partir } \\
\text { das dificuldades de } \\
\text { implementação é que se } \\
\text { reconheceu a necessidade } \\
\text { de processos participativos. }\end{array}$ & $\begin{array}{l}\text { Num processo contínuo } \\
\text { de aprendizado a prática } \\
\text { decisória participativa } \\
\text { começa a fazer parte do } \\
\text { cotidiano dos atores. }\end{array}$ & $\begin{array}{l}\text { São cada vez mais } \\
\text { participativos, pois os } \\
\text { atores têm reconhecido } \\
\text { a efetividade deste } \\
\text { processo em suas vidas }\end{array}$ \\
\hline Inclusão & $\begin{array}{l}\text { Não, haja vista que } \\
\text { a lógica que presidiu } \\
\text { foi a de construir para } \\
\text { e não com a própria } \\
\text { comunidade. }\end{array}$ & $\begin{array}{l}\text { Houve uma consideração } \\
\text { crescente pela inclusão } \\
\text { de outros atores (dos } \\
\text { pequenos produtores, } \\
\text { lavradores, quilombolas, } \\
\text { donas de casa etc.) }\end{array}$ & $\begin{array}{l}\text { É crescente o } \\
\text { amadurecimento quanto à } \\
\text { importância da diversidade } \\
\text { de atores em todo o } \\
\text { processo das políticas } \\
\text { públicas. }\end{array}$ & $\begin{array}{l}\text { Há uma dinâmica } \\
\text { não linear quanto à } \\
\text { participação. Contudo, } \\
\text { a inclusão tem se } \\
\text { tornado uma premissa } \\
\text { nas discussões } \\
\text { relativas ao DTS. }\end{array}$ \\
\hline
\end{tabular}

Fonte: Elaborado pelos autores.

\section{Considerações finais}

O objetivo deste artigo foi analisar, sob a ótica do DTS, a participação de diferentes atores na construção e implementação do Programa de Manejo Agroambiental da Bacia do Rio Almada. A falta de êxito dessa experiência local ocorrida no Território do Litoral Sul da Bahia explicase, principalmente, pela não participação da comunidade local e dos pequenos produtores rurais na construção da proposta enviada ao Ministério do Meio Ambiente em meados da década de 1990. 
Devido à prática top-down utilizada pelo grupo de técnicos e especialistas, as prefeituras, a comunidade local, as lideranças dos movimentos sociais, os pequenos produtores rurais foram ignorados durante a elaboração da proposta. Neste contexto, a "ponte" interligando diferentes saberes não ocorreu da maneira devida, muito provavelmente, porque o edital do Ministério do Meio Ambiente definiu um prazo exíguo, tanto para a elaboração como também para a implantação da proposta.

O estudo de caso explicitou negociações limitadas entre os diferentes atores, especialmente as comunidades mais pobres e excluídas. Os efeitos disso foram vistos na distância entre o poder público em suas diferentes instâncias e esferas resultando num ambiente desfavorável à articulação e ao diálogo entre as pessoas. Com isso, houve uma limitação no reconhecimento e valorização das características locais, assim como dos papéis das diferentes lideranças (especialmente dos moradores locais e pequenos produtores rurais). Portanto, é preciso considerar que os problemas vividos nos territórios dificilmente podem ser equacionados sem que exista, em maior ou menor grau, algum tipo de debate e diálogo efetivo entre os sujeitos.

Pode-se argumentar que a experiência em Almadina (BA) é um contraexemplo do que seja uma gestão social, pois, conforme argumentou Tenório (2005), ela se caracteriza pela participação, dialogismo e em situação em que o processo decisório é compartilhado por diferentes sujeitos. A despeito de o processo ter ocorrido de cima para baixo, deve-se observar que ao longo do processo houve a concordância de que o outro (pequenos produtores rurais e a comunidade local) deveria ser incluído na construção desta experiência (Tenório, 2005).

Retomando-se a pergunta de pesquisa: como ocorre a participação dos diferentes atores locais sob a lente da gestão social, da cidadania deliberativa e do desenvolvimento territorial sustentável? Foi possível concluir que há uma interseção teórica entre a gestão social, a cidadania deliberativa e o desenvolvimento territorial sustentável com as seguintes categorias: 1) Diálogo; 2) Construção social; 3) Participação e, finalmente, 4) Inclusão. Tais categorias de análise permitiram uma análise retrospectiva estruturada do caso, tendo como foco o DTS.

Diante das dificuldades iniciais de implementação (1998-2000), os diálogos com a comunidade se iniciaram e a inclusão de novos atores ocorreu paulatinamente, num processo não linear. Assim, a construção social das soluções contou com uma participação mais ativa dos atores ignorados no início da formulação da proposta. Houve o consenso de que a proposta era ousada e inovadora em seu momento de concepção (1996-98). Entretanto, hoje (2012) teria possibilidades de legitimação, pois os debates e diálogos têm se tornado uma prática mais frequente neste território, de tal forma que há um amadurecimento sobre a inclusão de novos atores nos processos decisórios. Dessa forma, os atores têm percebido a importância da participação na construção social dos projetos e programas no contexto do território sul baiano.

O caso em tela contribui para a reflexão sobre os desafios e oportunidades referentes à gestão social, indicando que o processo de cidadania deliberativa pode se constituir em estratégia necessária para o desenvolvimento territorial sustentável. Assim, fica claro que o diálogo, a participação dos atores, sobretudo os que são considerados beneficiários, na elabo- 
ração e implantação de políticas públicas é algo complexo, porém imprescindível, quando se almejam transformações das realidades sociais.

Além disso, o ocorrido em Almadina não parece ser algo isolado nas relações intergovernamentais, ou seja, quantas iniciativas espalhadas pelo Brasil não tiveram um destino semelhante ao ocorrido nesse território? Como tentar conciliar as políticas públicas federais e o respeito à diversidade econômica, social, política, cultural, ambiental dos demais territórios da cidadania? Nesse sentido, permanecem questões não respondidas, conforme nos alerta Dowbor (2006): "Como gerar um terreno mais favorável à inclusão produtiva do andar de baixo da economia, do 'circuito inferior'?".

Portanto, parece haver em torno destas questões um campo fértil para pesquisas futuras. Também é importante que se compreenda teoricamente a natureza dos laços sociais que se estabelecem entre os atores locais, ou seja, a natureza do processo de cooperação em torno do qual se constrói o território. Ainda que a cidadania deliberativa venha se consolidando na literatura sobre gestão social, consideram-se necessários outros estudos que abordem as práticas dos gestores públicos e demais atores envolvidos no processo de construção e implantação de políticas públicas em direção a um desenvolvimento territorial sustentável.

\section{Referências}

ABRAMOVAY, Ricardo. Para uma teoria dos estudos territoriais. In: VIEIRA, Paulo F. et al. (Org.). Desenvolvimento territorial sustentável no Brasil. Florianópolis: Aped; Secco, 2010.

ALLEBRANDT, Sérgio L. et al. A gestão social no contexto do programa Territórios da Cidadania. In: CANÇADO, Airton C.; TENÓRIO, Fernando G.; SILVA JR., Jeová T. (Org.). Gestão Social: aspectos teóricos e aplicações. Ijuí: Ed. Unijuí, 2012. p. 157-192.

ANDION, Carolina. Contribuições do debate sobre desenvolvimento territorial sustentável para a efetividade da gestão municipal. Política \& Sociedade, n. 14, p. 182-209, abr. 2009.

BEDUSCHI FILHO, Luis C.; ABRAMOVAY, Ricardo. Desafios para o desenvolvimento de regiões rurais. Nova Economia, v. 14, n. 3, p. 35-70, 2004.

BERG, Bruce L. Qualitative research methods for the social sciences. $5^{\text {th }}$ ed. Londres: Pearson, 2004. BERGER, Peter; LUCKMANN, Thomas. A construção social da realidade: tratado de sociologia do conhecimento. 22. ed. Petrópolis: Vozes, 2002.

BRASIL. MDA. SDT. Secretaria de Desenvolvimento Territorial. Estudo propositivo para dinamização econômica: território rural de Litoral Sul. Brasília, abr. 2007. Disponível em:<http://sit.mda.gov. br/biblioteca_virtual/ep/ep_territorio090.pdf $>$.

BRASIL. MDA. SDT. Secretaria de Desenvolvimento Territorial. Territórios da cidadania. Mar. 2009. Disponível em: <www.territoriosdacidadania.gov.br/dotlrn/clubs/territriosrurais/onecommunity>. 
BRASIL. PRONAT/SDT/MDA. Plano Territorial de Desenvolvimento Rural Sustentável. O que o Litoral Sul tem? Brasília: Ministério do Desenvolvimento Agrário - Secretaria de Desenvolvimento Territorial — SDT — Programa Nacional de Desenvolvimento Sustentável de Territórios Rurais — Pronat, 2006.

CARRION, Rosinha. A contribuição da gestão social para o desenvolvimento. In: CANÇADO, Airton C.; TENÓRIO, Fernando G.; SILVA JR., Jeová T. (Org.). Gestão social: aspectos teóricos e aplicações. Ijuí: Ed. Unijuí, 2012. p. 261-272.

CASSAB, Latif A. História oral: miúdas considerações para a pesquisa em serviço social. Serviço Social em Revista, Londrina, v. 5, n. 2, jan./jun. 2003. Disponível em: <www.ssrevista.uel.br/c_v5n2_latif. htm>. Acesso em: $12 \mathrm{dez} .2007$.

CASTEL, Robert. As metamorfoses da questão social: uma crônica do salário. Petrópolis: Vozes, 1998.

CAZELLA, Ademir. Contribuições metodológicas da socioantropologia para o desenvolvimento territorial sustentável. Eisforia, Florianópolis, ano 4, v. 4, n. especial, 2006.

CAZELLA, Ademir; BONNAL, Philippe; MALUF, Renato. Olhares disciplinares sobre o território e desenvolvimento territorial. In: CAZELLA, Ademir; BONNAL, Philippe; MALUF, Renato. Agricultura familiar: multifuncionalidade e desenvolvimento territorial no Brasil. Rio de Janeiro: Mauad X, 2009, p. 25-45.

CAZELLA, Ademir; CARRIÈRE, Jean-Pierre. Abordagem introdutória ao desenvolvimento territorial. Eisforia, Florianópolis, ano 4, v. 4, n. especial, p. 225-247, 2006.

DOWBOR, Ladislau. Gestão social e transformação da sociedade, 1999. Artigos online. Disponível em: <http://dowbor.org/8_gestaosocial.asp>. Acesso em: 20 ago. 2009.

DOWBOR, Ladislau. Redes de apoio ao desenvolvimento local: uma estratégia de inclusão produtiva, setembro 2006. Artigos online. Disponível em: < http://dowbor.org/06redesinclprodutivab. doc >. Acesso em: 2 abr. 2011.

ECHEVERRI, Rafael. Emergência e evolução do programa de desenvolvimento sustentável dos territórios rurais e nos territórios da cidadania. In: FAVARETO, Arilson. Políticas de desenvolvimento territorial rural no Brasil: avanços e desafios. Brasília: IICA, 2010. v. 12, p. 81-103.

EISENHARDT, Kathleen M. Building theories from case study research. The Academy of Management Review, v. 14, n. 4, p. 532-550, Oct. 1989.

FAVARETO, Arilson. A abordagem territorial do desenvolvimento rural: mudança institucional ou inovação por adição? Estudos Avançados, São Paulo, v. 24, n. 68, p. 299-319, 2010.

FERNANDES, Antônio S. A. Manejo integrado da bacia hidrográfica do rio Almada. In: FUJIWARA, Luis M.; ALESSIO, Nelson N.; FARAH, Marta F. S. (Org.). 20 experiências de gestão pública e cidadania. São Paulo: Programa Gestão Pública e Cidadania, 1999. p. 3-15.

FERRAZ, José Maria G. Agroecologia. DF: Ministério da Agricultura, Pecuária e Abastecimento — Agência de Informação Embrapa. Disponível em: <www.agencia.cnptia.embrapa.br/gestor/agricultura_e_meio_ambiente/arvore/CONTAG01_8_299200692526.html>. Acesso em: 20 set. 2012. 
FISCHER, Tânia M. D. Poderes locais, desenvolvimento e gestão — uma introdução a uma agenda. In: FISCHER, Tânia M. D. (Org.). Gestão do desenvolvimento e poderes locais: marcos teóricos e avaliação. Salvador: Casa da Qualidade, 2002. p. 12-32.

FISCHER, Tânia M. D.; MELO, Vanessa P. Programa de Desenvolvimento e Gestão Social: uma construção coletiva. In: FISCHER, Tânia; ROESCH, Sylvia; MELO, Vanessa P. Gestão do desenvolvimento territorial e residência social: casos para ensino. Salvador: EDUFBA; Ciags/UFBA, 2006. p. 13-41.

FONTAN, Jean-Marc; KLEIN, Juan-Luis; LEVESQUE, Benoit (Ed.) Réconversion économique et développement territorial. Quebec: Presses Universitaires du Québec, 2003.

FRANÇA FILHO, Genauto C. Definindo gestão social. In: SILVA JR., Jeová; MÂSIH, Rogerio et al. (Org.). Gestão social: práticas em debate, teorias em construção. Fortaleza: Imprensa Universitária, 2008. p. 27-37.

FRANÇA FILHO, Genauto C. Gestão social: um conceito em construção. In: COLÓQUIO INTERNACIONAL SOBRE PODER LOCAL, IX, COLÓQUIO INTERNACIONAL EL ANÁLISIS DE LAS ORGANIZACIONES Y LA GESTIÓN ESTRATÉGICA: Perspectivas Latinas, II, 2003, Salvador.

FREIRE, Paulo. Pedagogia do oprimido. Rio de Janeiro: Paz e Terra, 2005.

GOHN, Maria da G. Conselhos gestores e participação sociopolítica. São Paulo: Cortez, 2003.

HABERMAS, Jürgen. Mudança estrutural da esfera pública: investigações quanto a uma categoria da sociedade burguesa. Rio de Janeiro: Tempo Brasileiro, 2003.

HABERMAS, Jürgen. Teoria de la acción comunicativa. Traducción de Manuel Jiménez Redondo. Madri: Taurus, 1987. 2 v.

IBGE. Censos Demográficos, 2000, 2010. IBGE-Cidades (em parceria com os Órgãos Estaduais de Estatística e Secretarias Estaduais de Governo). 2010. Disponível em: <www.ibge.gov.br/cidadesat/topwindow.htm?>. Acesso em: 20 out. 2011.

IIZUKA, Edson S. et al. Gestão social e cidadania deliberativa: a experiência de ilha Comprida — São Paulo. Cadernos Ebape.BR, Rio de Janeiro, v. 9, n. 3, art. 4, p. 749-779, set. 2011.

IIZUKA, Edson S. Fluxos de ações e processos decisórios na gestão pública local: estudos de casos de projetos e programas inovadores em municípios de pequeno porte populacional. Tese (doutorado) — Fundação Getulio Vargas, São Paulo, 2008.

JEAN, Bruno. Do desenvolvimento regional ao desenvolvimento territorial sustentável: rumo a um desenvolvimento territorial solidário para um bom desenvolvimento dos territórios rurais. In: VIEIRA, Paulo F. et al. (Org.). Desenvolvimento territorial sustentável no Brasil. Florianópolis: Aped; Secco, 2010. p. 45-68.

LÉVESQUE, Benoit. Contribuição da nova sociologia econômica para repensar a economia no sentido do desenvolvimento sustentável. Revista de Administração de Empresas, São Paulo, v. 47, n. 2, p. 49-60, abr./jun. 2007. 
MAIA, Marilena. Gestão social: reconhecendo e construindo referenciais. Revista Virtual Textos \& Contextos, ano IV, n. 4, dez. 2005. Disponível em: < http://revistaseletronicas.pucrs.br/ojs/index. php/fass/article/view/1010/790>. Acesso em: 20 set. 2012.

MAY, Peter H.; ROCHA, Rui B. O sistema agrossilvicultural do cacau-cabruca. In: LOPEZ, Ignez V. et al. (Org.). Gestão ambiental no Brasil: experiências de sucesso. Rio de Janeiro: Fundação Getulio Vargas, 1998. p. 35-62.

MILANI, Carlos R. S. O princípio da participação na gestão de políticas públicas locais: uma análise de experiências latino-americanas e europeias. Revista de Administração Pública, Rio de Janeiro, v. 42, n. 3, p. 551-579, maio/jun. 2008.

NOGUEIRA, Marco Aurélio. Um Estado para a sociedade civil: temas éticos e políticos da gestão democrática. São Paulo: Cortez, 2004.

PECQUEUR, Bernard. Le developpement territorial: une nouvelle approche des processus de développement pour les économies du Sud. In: ANTHEAUME, Benoit; GIRAUT, Frederic (Ed.). Le territoire est mort. Vive les territoires. Paris: IRD, 2005. p. 295-316.

SACHS, Ignacy (Org.). Rumo à ecossocioeconomia: teoria e prática do desenvolvimento. São Paulo: Cortez, 2007.

SARAVIA, Enrique. La participación de la comunidad en la implementación de políticas públicas: el caso de las políticas de alfabetización y de inclusión digital en Minas Gerais, Brasil. In: MARIÑEZ, Freddy; VIDAL, Garza C. (Org.). Política pública y democracia en América Latina. Mexico, DF: TEC; Egap, 2009. p. 243-254.

SAWAIA, Bader. As artimanhas da exclusão: análise psicossocial e ética da desigualdade social. Rio de Janeiro: Vozes, 1999.

SEPÚLVEDA, Sergio; GUIMARÃES, Marcelo D. Gestión del desarrollo sostenible en territorios rurales en Brasil. San José, CR: IICA, 2008.

TENÓRIO, Fernando G. (Re)visitando o conceito de gestão social. Desenvolvimento em Questão, Ijuí, v. 3, n. 5, p. 101-124, jan./jul. 2005.

TENÓRIO, Fernando G. Cidadania e desenvolvimento local: casos brasileiros. In: CONGRESO INTERNACIONAL DEL CLAD SOBRE LA REFORMA DEL ESTADO Y DE LA ADMINISTRACIÓN PÚBLICA, 9, 2004, Madri. Proceedings...Madri: 2004. Disponível em: <www.gp.usp.br/files/desen_cidadania. pdf>. Acesso em: 18 set. 2012.

TENÓRIO, Fernando G. et al. Critérios para avaliação de processos decisórios participativos deliberativos na implementação de políticas públicas. In: ENCONTRO DE ADMINISTRAÇÃO PÚBLICA E GOVERNANÇA. Anais... Salvador: Anpad, 2008.

TENÓRIO, Fernando G. Gestão social um conceito não idêntico? Ou a insuficiência inevitável do pensamento. In: CANÇADO, Airton C.; TENÓRIO, Fernando G.; SILVA JR., Jeová T. (Org.). Gestão social: aspectos teóricos e aplicações. Ijuí: Ed. Unijuí, 2012. p. 23-36. 
TENÓRIO, Fernando G. Gestão social: uma réplica. In: RIGO, Ariádne S.; SILVA JÚNIOR, Jeová T.; SCHOMMER, Paula C.; CANÇADO, Airton C. Gestão social e políticas públicas de desenvolvimento: ações, articulações e agenda. Recife: Univasf, 2010.

TENÓRIO, Fernando G. Um espectro ronda o terceiro setor: o espectro do mercado. 3. ed. Ijuí: Editora da Unijuí, 2008.

TENÓRIO, Fernando G.; SILVA JR., Jeová T. (Org.). Gestão social: aspectos teóricos e aplicações. Ijuí: Ed. Unijuí, 2012.

VERENA, Alberti. Manual de história oral. Rio de Janeiro: Ed. FGV, 2004.

VERGARA, Sylvia C. Métodos de pesquisa em administração. São Paulo: Atlas, 2005.

VIEIRA, Paulo F. Gestão de recursos comuns para o ecodesenvolvimento. In: VIEIRA, Paulo F. et al. Gestão integrada e participativa de recursos naturais: conceitos, métodos e experiências. Florianópolis: Secco/Aped, 2005. p. 35-52.

VIEIRA, Paulo F.; CAZELLA, Ademir A. Desenvolvimento territorial sustentável em zonas rurais: subsídios para a elaboração de um modelo de análise. In: SEMINARIO INTERNACIONAL TERRITORIOS RURALES EN MOVIMIENTO, 2006, Chile. Anais... Santiago do Chile: IDRC-CRDI, 2006.

VILLELA, Lamounier E.; COSTA, Eduardo G. Avaliação de processos decisórios participativos no polo comercial Saara situado na cidade do Rio de Janeiro. In: CANÇADO, Airton C.; TENÓRIO, Fernando G.; SILVA JR., Jeová T. (Org.). Gestão social: aspectos teóricos e aplicações. Ijuí: Ed. Unijuí, 2012. p. 57-86.

WEICK, Karl E. Sensemaking in organizations. Thousand Oaks: Sage, 1995.

YIN, Robert K. Estudo de caso: planejamento e métodos. 3. ed. Porto Alegre: Bookman, 2005.

ZANI, Felipe B. O programa de desenvolvimento territorial sustentável dos territórios rurais pela ótica da cidadania deliberativa. In: TENÓRIO, Fernando G. (Org.). Cidadania e desenvolvimento local: critérios de análise. Rio de Janeiro: Editora da FGV, 2012. v. 1, p. 181-206.

ZANI, Felipe B.; KRONEMBERGER, Thais S.; DIAS, Anderson F. Gestão social aplicada às políticas públicas de desenvolvimento territorial rural no Brasil. In: CANÇADO, Airton C.; TENÓRIO, Fernando G.; SILVA JR., Jeová T. (Org.). Gestão social: aspectos teóricos e aplicações. Ijuí: Ed. Unijuí, 2012. p. 1-264.

Edson Sadao Iizuka é docente colaborador na Pontifícia Universidade Católica de São Paulo (PUC-SP) e docente permanente da Fundação Escola de Comércio Álvaro Penteado (Fecap). E-mail: esadao@ pucsp.br.

Sylmara Lopes Francelino Goncalves-Dias é professora doutora da Escola de Artes, Ciências e Humanidades da Universidade de São Paulo (USP). E-mail: sgdias@usp.br.

Pedro Aguerre é doutor em ciências sociais pela PUC-SP e professor da Faculdade de Administração da PUC-SP. E-mail: pedroaguerre@uol.com.br. 
